\title{
Tofacitinib in the management of ulcerative colitis refractory to anti-TNF and anti-integrin therapies
}

\author{
Fábio Vieira TEIXEIRA ${ }^{1}$, Adérson Omar Mourão Cintra DAMIÃO² and Paulo Gustavo KOTZE ${ }^{3}$
}

Received 17/1/2018

Accepted 22/1/2018

\begin{abstract}
Janus kinases inhibitors have already been incorporated into the management of immune-mediated diseases, such as rheumatoid arthritis, and are being investigated for the treatment of psoriasis and inflammatory bowel diseases, both ulcerative colitis and Crohn's disease. Tofacitinib is an oral small-molecule drug that inhibits Janus kinases 1, Janus kinases 3, and, to a lesser extent, Janus kinases 2. This inhibition ends up blocking signals for several inflammatory cytokines that are involved in the pathogenesis of inflammatory bowel diseases and play a role in many immune signaling routes, including lymphocyte activation, function, and proliferation. We report a patient with active ulcerative colitis with primary non-response to three biologics (infliximab, adalimumab and vedolizumab), with different mechanisms of action, who refused surgical treatment and had a favorable response to tofacitinib with clinical and endoscopic remission. No adverse events were observed with the use of the agent. This case illustrates the difficulties we may face regarding the identification of the expression of proper mechanism of action involved in the pathogenesis of ulcerative colitis patients and the importance of having another treatment option with different mechanism of action, like tofacitinib.
\end{abstract}

HEADINGS - Proctocolitis, therapy. Biological factors. Monoclonal antibodies. Janus kinase inhibitors, therapeutic use.

\section{INTRODUCTION}

The pathogenesis of ulcerative colitis (UC) is multifactorial and comprises genetic, environmental, microbial, and immune response components ${ }^{(1)}$ The current treatment algorithm of UC includes glucocorticoids, aminosalicylates, immunosuppressants, anti-tumour necrosis factor (TNF) agents and, more recently, anti-integrins ${ }^{(2)}$. The introduction of anti-TNF agents, such as infliximab (IFX) and adalimumab (ADA), has improved UC treatment with reduction of hospitalizations and surgery ${ }^{(3,4)}$. However, anti-TNF therapy has significant rates of loss of response and higher infectious adverse events rates, when compared to other therapies $^{(5,6)}$. Vedolizumab (VEDO), an anti $\alpha 4 \beta 7$ integrin, on the other hand, has shown efficacy and an adequate safety profile, due to gut-selectivity properties. Thus, as every new biologic agent in the market, price and reimbursement are still an important issue, specially in developing countries such as Brazil ${ }^{(7)}$.

Janus kinase (JAK) inhibitors are small molecules that are currently under investigation for the treatment of several immune diseases including psoriasis, rheumatoid arthritis (RA) and alopecia areata. In late 2014, tofacitinib (TOFA), a JAK inhibitor, has granted marketing authorization by ANVISA (Agência Nacional de Vigilancia Sanitária) for the treatment of RA in Brazil. TOFA has also being tested in other immune-mediated diseases like $\mathrm{UC}^{(8,9)}$.

The aim of this brief communication is to describe in detail a case of a UC patient with primary non-response to anti-TNF agents (IFX and ADA) and an anti-integrin (VEDO), who was successfully treated with TOFA.

\section{THE DIFFICULT ULCERATIVE COLITIS PATIENT}

A 44-year-old man was electively admitted to an outpatient private clinic with an 8-week history of bloody diarrhea. He had been diagnosed with $\mathrm{UC}$ for 3 years and was maintained in remission with oral mesalamine MMX $2.4 \mathrm{~g} /$ day in combination with azathioprine $2 \mathrm{mg} / \mathrm{kg} / \mathrm{day}$, until a flare with gradual onset of bloody diarrhea. His bowel frequency was 10 times per day, associated with significant abdominal pain, tenesmus and weight loss of $10 \mathrm{~kg}$. Over the previous 8 weeks of admission to our unit, he started prednisone $40 \mathrm{mg}$ per day with symptomatic improvement. However, symptoms recurred right after reduction of the dose of steroids. His vital signs were stable and no remarkable findings were seen during clinical and abdominal examination. Laboratory investigations revealed a hemoglobin of $10.2 \mathrm{~g} / \mathrm{dL}, \mathrm{C}$-reactive protein (CRP) of $75.0 \mathrm{mg} / \mathrm{L}$, white blood count of $6.1 \times 10^{9}$, an albumin of $31.0 \mathrm{~g} / \mathrm{L}$, and a fecal calprotectin of $450 \mu \mathrm{g} / \mathrm{g}$.

Ileocolonoscopy demonstrated oedema, erosions, friability, spontantaneous bleeding and ulcerations from the rectosigmoid junction extending to the transverse colon (Mayo endoscopic subescore of 3) (FIGURE 1A). In view of these findings, a decision to start IFX $5 \mathrm{mg} / \mathrm{kg}$ at weeks 0,2 , and 6 , and then every 8 weeks, in combination with azathioprine, $2 \mathrm{mg} / \mathrm{kg} / \mathrm{day}$, was made. After 20 weeks on IFX therapy, the patient was still symptomatic. CRP was still elevated, $25.0 \mathrm{mg} / \mathrm{L}$, and fecal calprotectin increased to 550 $\mu \mathrm{g} / \mathrm{g}$. Flexible sigmoidoscopy showed no significant improvement, with similar endoscopic findings (FIGURE 1B). After discussing the options with the patient, we decided to switch to subcutaneous

Declared conflict of interest of all authors: Teixeira FV is a speaker and consultant for Janssen, Ferring, Abbvie and Takeda; advisory board for Ferring and Janssen. Damião AOMC is a speake and consultant for Abbvie, Janssen, Pfizer and Takeda. He is also an employee of Nestle. Kotze PG is a speaker and consultant of Abbvie, Janssen, Takeda and Pfizer.

Disclosure of funding: no funding received

Studied carried out at Gastrosaúde, Marilia, SP, Brazil.

${ }^{1}$ Clínica GastroSaúde, Marília, SP, Brasil; ${ }^{2}$ Universidade de São Paulo, Faculdade de Medicina, Departamento de Gastroenterologia, São Paulo, SP, Brasil; ${ }^{3}$ Pontifícia Universidade Católica do Paraná, Hospital Universitário Cajuru, Serviço de Coloproctologia, Curitiba, PR, Brasil.

Correspondence: Paulo Gustavo Kotze. E-mail: pgkotze@hotmail.com 
ADA $160 \mathrm{mg}$ at week $0,80 \mathrm{mg}$ at week 2 and $40 \mathrm{mg}$ every other week. The patient was evaluated 3 months after treatment, with no clinical and laboratory improvement. We defined him as a primary non-responder to IFX and ADA, and decided to start a biological agent with a different mechanism of action.

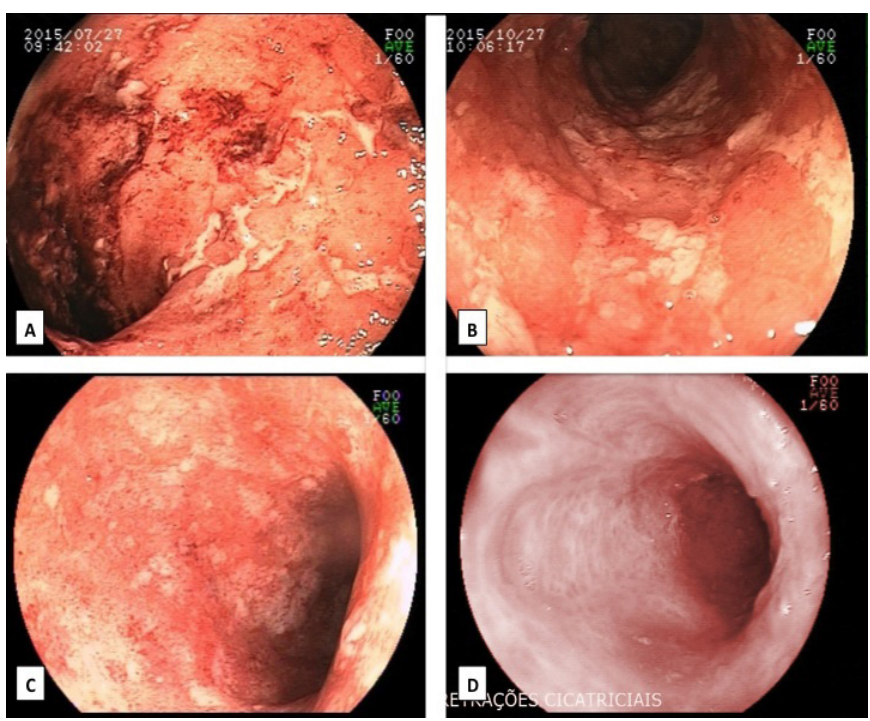

FIGURE 1 A/D. Endoscopic aspects during treatment evolution. A First ileocolonoscopy, before infliximab therapy. Severely active disease. B: Flexible sigmoidoscopy after infliximab therapy, before switching to adalimumab. Persistence of active inflammation. C: Flexible sigmoidoscopy after infliximab, adalimumab and vedolizumab therapy. Still active disease. D: Mucosal healing after 8 weeks of tofacitinib therapy.

A switch to intravenous VEDO, $300 \mathrm{mg}$ weeks 0,2 , and 6, and then every 8 weeks was attempted. At week 22 , the patient was still symptomatic, malnourished and referred mild improvement of symptoms. In addition to that, all laboratory exams were still abnormal (hemoglobin $10.7 \mathrm{~g} / \mathrm{dL}$, CRP $94,0 \mathrm{mg} / \mathrm{L}$, albumin 25 $\mathrm{g} / \mathrm{L}$ and fecal calprotectin of $470 \mu \mathrm{g} / \mathrm{g}$ ). Clostridium difficile toxins $\mathrm{A}$ and $\mathrm{B}$ and $\mathrm{CMV}$ serology were both negative. Another flexible sigmoidoscopy revealed persistance of inflammation (FIGURE 1C). Oedema, friability, multiple erosions, and ulcerations were still present (Mayo endoscopic subscore of 2). In view of the primary non-response to three biological agents, two anti-TNFs and one anti-integrin, a subtotal colectomy with a temporary ileostomy was indicated and discussed with the patient. He refused to be operated and be given an ileostomy.

As an alternative, we offered him an off-label treatment with TOFA, after a detailed discussion of the pros and cons of postponing surgery. Oral TOFA, $10 \mathrm{mg}$ bid, was then initiated. Eight weeks after starting the treatment, the patient referred a remarkable symptomatic improvement, with no diarrhea and bleeding. The laboratory results also demonstrated significant improvement: hemoglobin $11.4 \mathrm{~g} / \mathrm{dL}, \mathrm{CRP} 14.0 \mathrm{mg} / \mathrm{L}$, albumin $33.0 \mathrm{~g} / \mathrm{L}$ and fecal calprotectin of $250 \mu \mathrm{g} / \mathrm{g}$ and normal cholesterol levels. No adverse events were detected during the treatment. We de-escalated the dose of TOFA to $5 \mathrm{mg}$ bid for maintenance. A flexible sigmoidoscopy was performed 3 months after starting TOFA, and revealed full mucosal healing of the sigmoid and rectum (FIGURE 1D), with a Mayo endoscopic subscore of 0 . The patient was followed for 6 months, with sustained clinical and laboratory remission, with ongoing maintenance therapy.

\section{DISCUSSION}

More than $80 \%$ of UC patients respond to aminosalicylates and less than one third of them will need biological therapy during the disease course $^{(2)}$. When salicylates fail, thiopurines (azathioprine and 6-MP) are a valuable option, especially in steroid dependent patients $^{(2)}$. Anti-TNF therapy (IFX, ADA and golimumab) have turned out to be the treatment of choice in UC patients who are refractory to conventional therapy ${ }^{(2)}$. However, the treatment with anti-TNF drugs has some drawbacks. It is associated with loss of response in long term (approximately 13\% per year), mainly due to neutralizing antibody formation ${ }^{(5)}$. Moreover, anti-TNF therapy is associated with potential adverse events ${ }^{(6)}$. The last TREAT registry reported an increased rate of severe infections (opportunistic infections, tuberculosis, histoplasmosis, etc.) in inflammatory bowel diseases (IBD) patients treated with IFX, when compared to conventional therapy ${ }^{(6)}$. Recently, a gut-specific biological agent (VEDO) became available for UC patients, with a potential advantage of having no systemic immunossupression, what can improve the safety profile during treatment ${ }^{(10)}$.

We reported here an unusual case of a UC patient who was treated with three biological agents (IFX, ADA and VEDO) after being refractory to conventional therapy. The patient was a primary non-responder to three biologicals with different mechanisms of action: TNF inhibition and $\alpha 4 \beta 7$ blockage. After considering all the available options, we first recommended colectomy. As the patient refused the surgical option, which is not uncommon in this scenario, due to fear of permanent stomas, we proposed an off-label treatment with a JAK inhibitor (TOFA) ${ }^{(11)}$. Clearly, at this point, an attempt with cyclosporine could be made. However, as the patient failed previous therapy with azathioprine, maintenance therapy after induction would remain a significant problem.

JAK inhibitors have already been incorporated in the management of immune-mediated diseases such as RA (in Brazil, since late $2014)^{(7)}$. The drug is currently being investigated for the treatment of psoriasis and IBD ${ }^{(12-15)}$. TOFA (CP-690,550) is an oral small-molecule drug (SMD) with a molecular weight of 312.3 Da. It inhibits JAK1, JAK3, and, to a lesser extent, JAK $2^{(13-15)}$. This inhibition ends up blocking signals for several inflammatory cytokines such as interleukin (IL)-2, IL-4, IL-6, IL-7, IL-9, IL-15, IL-21 and interferon-gama, among others ${ }^{(13-15)}$. These cytokines are involved in the pathogenesis of IBD and play a role in many immune signaling routes including lymphocyte activation, function, and proliferation ${ }^{(12-15)}$.

The initial favorable results of TOFA in a phase II multicenter randomized trial in UC, prompted a phase III program (OCTAVE) investigating the efficacy and safety of induction and maintenance therapy in patients with moderately to severely active $\mathrm{UC}^{(8,9)}$. In the OCTAVE induction 1 trial ( $n=476$ in the TOFA group; $n=122$ in the placebo group) remission at 8 weeks (defined as a total Mayo score of $\leq 2$, with no subscore $>1$ and a rectal bleeding subscore of 0 ) was $18.5 \%$ in the TOFA group (10 mg twice daily, oral) versus $8.2 \%$ in the placebo group $(P=0.007)$. In the OCTAVE induction 2 trial, with similar methodology, remission at 8 weeks was observed in $16.6 \%$ in the TOFA group versus $3.6 \%$ with placebo $(P<0.001)^{(9)}$. An interesting observation was that in both trials the treatment effects were similar between those who had received previous treatment with a TNF antagonist and those who had not ${ }^{(9)}$. In the OCTAVE sustain trial, two maintenance doses, $10 \mathrm{mg}$ twice daily $(\mathrm{n}=197)$ and $5 \mathrm{mg}$ twice daily $(\mathrm{n}=198)$ were compared with placebo $(n=198)$ for 52 weeks in patients who completed the OCTAVE 1 or 2 trials and had a clinical response defined as a decrease in the total Mayo score of at least three points, with an accompanying 
decrease in the rectal bleeding subscore of at least one point or an absolute rectal bleeding subscore of 0 or 1 . Remission at 52 weeks was $34.3 \%$ and $40.6 \%$ in the $5 \mathrm{mg}$ and $10 \mathrm{mg}$ TOFA groups, respectively, compared with $11.1 \%$ in the placebo group $(P<0.001$ for both comparisons with placebo $)^{(9)}$. In the OCTAVE induction 1 and 2 trials, the key secondary endpoint of mucosal healing, defined as a Mayo endoscopic subscore $\leq 1$, at 8 weeks, occurred in significantly more patients in the TOFA group than in the placebo group (OCTAVE 1: $31.3 \%$ TOFA x $15.6 \%$ placebo; $P<0.001$ ). Again, previous treatment with a TNF antagonist seemed not to influence the results. In the OCTAVE sustain trial, mucosal healing at 52 weeks was $37.4 \%$ and $45.7 \%$ in the $5 \mathrm{mg}$ and $10 \mathrm{mg}$ TOFA groups, respectively, versus $13.1 \%$ in the placebo group $(P<0.001$ for both comparisons $)^{(9)}$. These findings emphasize that patients with previous exposure to biological agents, mainly anti-TNFs, can still have TOFA as an important option, as remission can be observed and mucosal healing can be observed in $30 \%-45 \%$ of patients. This was exactly the outcome observed in our patient.

A numerically higher rate of herpes zoster infection (usually less than $1.5 \%$ ) was observed in the TOFA groups in the maintenance trial, mainly with the higher dose (10 mg twice daily). No case of herpes zoster infection was considered serious or resulted in discontinuation of the $\mathrm{drug}^{(9)}$. Across the three trials, lipid levels (i.e., cholesterol levels, LDL and HDL) increased with TOFA (usually in less than $30 \%$ of patients) and the increased plateaued after approximately 4 weeks $^{(9)}$. Among patients with RA or psoriasis,
TOFA has also been associated with an increase in lipid levels without an increased risk of cardiovascular events. More cases of non-melanoma skin cancer occurred with TOFA (five cases) than with placebo (one case) across the OCTAVE trials. All cases had previous exposure to thiopurines. No cases of tuberculosis were reported in the three trials. Our patient did not develop any adverse event during TOFA therapy. However, the follow-up period with the drug was short, and monitoring is currently ongoing. Data from the ongoing open-label extension trial (OCTAVE open) of TOFA in UC may further elucidate the long-term safety profile of this drug ${ }^{(9)}$.

In summary, we briefly communicated a patient with active UC with primary non-response to three biological agents, with different mechanisms of action, who refused surgical treatment and had a favorable response to TOFA, with clinical and endoscopic remission. No adverse events were observed with the use of the drug. This case illustrates the difficulties in managing refractory UC patients in an era of many biologicals as therapeutic options. It also emphasized the importance of a new mechanism of action as inhibition of JAKs, as a valid option in the therapeutic armamentarium in UC. Approval of TOFA by regulatory agencies worldwide is awaited, and growing expertise with the use of the drug is a question of time.

\section{Authors' contribution}

Teixeira FV, Damião AOMC and Kotze PG drafted the article and all authors gave final revision and permission for publication.

Teixeira FV, Damião AOMC, Kotze PG. Uso do tofacitinibe na retocolite ulcerativa refratária ao tratamento com anti-TNF e anti-integrina. Arq Gastroenterol. 2018;55(2):198-200.

RESUMO - Os inibidores das Janus kinases (JAK) têm sido incorporados ao tratamento de doenças imunomediadas, como artrite reumatoide e, além disso, têm sido testados no tratamento da psoríase e doenças inflamatórias intestinais, tanto na retocolite ulcerativa quanto na doença de Crohn. Tofacitinibe é uma droga do grupo das pequenas moléculas de uso oral que inibe as Janus kinases 1 e 3 e, em menor grau, a Janus kinases 2 . Esta inibição promove o bloqueio de uma série de citocinas pró-inflamatórias que estão envolvidas na patogênese das doenças inflamatórias intestinais e desempenham importante papel nos processos imunes, tais como ativação, função e proliferação linfocitária. Nesta presente comunicação, relatamos um caso de um paciente portador de retocolite ulcerativa refratária a três agentes biológicos (infliximabe, adalimumabe e vedolizumabe), com diferentes mecanismos de ação, que recusou o tratamento cirúrgico, porém, apresentou boa resposta com o uso de tofacitinibe, com remissão clínica e endoscópica. Não foram evidenciados efeitos colaterais com a droga. O presente caso ilustra as dificuldades que podemos enfrentar em relação à identificação da expressão do correto mecanismo de ação envolvido na patogênese dos pacientes com retocolite ulcerativa e a importância de um novo agente terapêutico com diferente mecanismo de ação, como o tofacitinibe.

DESCRITORES - Proctocolite, terapia. Fatores biológicos. Anticorpos monoclonais. Inibidores de Janus quinases, uso terapêutico.

\section{REFERENCES}

1. Danese S, Fiochi C. Ulcerative colitis. N Engl J Med. 2011;365:1713-25.

2. Harbord M, Eliakim R, Bettenworth D, Karmiris K, Katsanos K, Kopylov U, et al. Third European Evidence-based Consensus on Diagnosis and Management of Ulcerative Colitis. Part 2: Current Management. J Crohns Colitis. 2017;11:769-84.

3. Danese S, Fiorino G, Peyrin-Biroulet L, Lucenteforte E, Virgili G, Moja L, Bonovas S. Biological Agents for Moderately to Severely Active Ulcerative Colitis. A Systematic Review and Network Meta-analysis. Ann Intern Med. 2014;160:704-11.

4. Kaplan GG, Seow CH, Ghosh S, Molodecky N, Rezaie A, Moran GW, et al Decreasing colectomy rates for ulcerative colitis: a population-based time trend study. Am J Gastroenterol. 2012;107:1879-87.

5. Gisbert JP, Panés J. Loss of Response and Requirement of Infliximab Dose Intensification in Crohn's Disease: A Review. Am J Gastroenterol. 2009;104:760-7.

6. Lichtenstein GR, Feagan BG, Cohen RD, Salzberg BA, Diamond RH, Price S, et al. Serious infection and mortality in patients with Crohn's disease: more than 5 years of follow-up in the TREAT ${ }^{\mathrm{TM}}$ registry. Am J Gastroenterol. 2012;107:1409-22.

7. da Mota LM, Cruz BA, de Albuquerque CP, Gonçalves DP, Laurindo IM, Pereira IA, et al. Update on the 2012 Brazilian Society of Rheumatology Guidelines for the treatment of rheumatoid arthritis: position on the use of tofacitinib. Rev Bras Reumatol. 2015;55:512-21.

8. Sandborn WJ, Ghosh S, Panes J, Vranic I, Su C, Rousell S, et al. Tofacitinib, an oral Janus kinase inhibitor, in active ulcerative colitis. N Engl J Med. 2012;367:616-24
9. Sandborn WJ, Su C, Sands BE, D'Haens GR, Vermeire S, Schreiber S, et al OCTAVE Induction 1, OCTAVE Induction 2, and OCTAVE Sustain Investigators. Tofacitinib as Induction and Maintenance Therapy for Ulcerative Colitis. N Engl J Med. 2017;376:1723-36.

10. Dart RJ, Samaan MA, Powell N, Irving PM. Vedolizumab: toward a personalized therapy paradigm for people with ulcerative colitis. Clin Exp Gastroenterol 2017; 10:57-66

11. Siegel CA, Schwartz LM, Woloshin S, Cole SB, David T, Rubin DT, et al. When Should Ulcerative Colitis Patients Undergo Colectomy for Dysplasia? Mismatch Between Patient Preferences and Physician Recommendations. Inflamm Bowel Dis. 2010;16:1658-62.

12. Boland BS, Sandborn WJ, Chang JT. Update on Janus kinase antagonists in inflammatory bowel disease. Gastroenterol Clin North Am. 2014:43:603-17.

13. Olivera P, Danese S, Peyrin-Biroulet L. Next generation of small molecules in inflammatory bowel disease. Gut. 2017;66:199-209.

14. Olivera P, Danese S, Peyrin-Biroulet L. JAK inhibition in inflammatory bowel disease. Exp Rev Clin Immunol. 2017;13:693-703.

15. De Vries LCS, Wildenberg ME, De Jonge WJ, D’Haens GR. The future of Janus Kinase inhibitors in inflammatory bowel disease. J Crohn's Colitis. 2017;11:885-93.

(cC) BY-NC 